\title{
The Numba ductile deformation zone (northwest Cameroon): A geometric analysis of folds based on the Fold Profiler method
}

\author{
T Njanko ${ }^{1,2, *}$, C Nuiki Chatué ${ }^{1}$, M Kwékam ${ }^{1}$, B E Bella NkÉ ${ }^{1}$, \\ A F YAKeu SANDJO ${ }^{1,3}$ and E M Fozing ${ }^{1}$ \\ ${ }^{1}$ Laboratory of Environmental Geology, The University of Dschang, P.O. Box 67, Dschang, Cameroon. \\ ${ }^{2}$ Ministry of Scientific Research and Innovation, DPSP/CCAR, P.O. Box 1457, Yaoundé, Cameroon. \\ ${ }^{3}$ Ministry of Water Resources and Energy, CRD, Gas and Petroleum Products Service, P.O. Box 8020, \\ Yaoundé, Cameroon. \\ *Corresponding author. e-mail: tnjanko@gmail.com
}

The Numba ductile deformation zone (NDDZ) is characterised by folds recorded during the three deformation phases that affected the banded amphibole gneiss. Fold-shape analyses using the program Fold Profiler with the aim to show the importance of folding events in the structural analysis of the NDDZ and its contribution to the Pan-African orogeny in central Africa have been made. Classical field method, conic sections method and Ramsay's fold classification method were applied to (i) have the general orientation of folds, (ii) analyze the fold shapes and (iii) classify the geometry of the folded bands. Fold axes in banded amphibole gneiss plunge moderately $\left(<15^{\circ}\right)$ towards the NNE or SSW. The morphology of $\mathrm{F}_{1}, \mathrm{~F}_{2}$ and $\mathrm{F}_{3}$ folds in the study area clearly points to (i) Z-shape folds with $\mathrm{SE}$ vergence and (ii) a dextral sense of shear motion. Conic section method reveals two dominant families: $\mathrm{F}_{1}$ and $\mathrm{F}_{3}$ folds belong to parabolic shape folds, while $\mathrm{F}_{2}$ folds belong to parabolic shape and hyperbolic shape folds. Ramsay's scheme emphasizes class $1 \mathrm{C}$ (for $\mathrm{F}_{1}, \mathrm{~F}_{2}$ and $\mathrm{F}_{3}$ folds) and class 3 (for $\mathrm{F}_{2}$ folds) as main fold classes. The co-existence of the various fold shapes can be explained by (i) the structuration of the banded gneiss, (ii) the folding mechanisms that associate shear with a non-least compressive or flattening component in a ductile shear zone and (iii) the change in rheological properties of the band during the period of fold formation. These data allow us to conclude that the Numba region underwent ductile dextral shear and can be integrated (i) in a correlation model with the Central Cameroon Shear Zone (CCSZ) and associated syn-kinematic intrusions and (ii) into the tectonic model of Pan-African belt of central Africa in Cameroon.

\section{Introduction}

Different types of strain patterns appearing in folded regions and their geometrical evolution from initial, undeformed stage, to the final fold are a matter of significance to kinematic studies of folding (Aller et al. 2010). The Numba basement rock has been affected by three ductile deformation events recorded in banded amphibole gneiss and are marked by several folding structures. Folds are the concrete structures that mark these different events. Up until now, apart from the recent research works of Ganno et al. (2010), the basement rock of the northern domain of the Central African

Keywords. Fold classification; Numba; Cameroon; Pan-African. 
Pan-African Belt (CAPB) in Cameroon has not yet been characterised using folds analysis. The northwest Cameroon basement rock, part of the CAPB, is poorly documented. It is important to understand the tectonic evolution of the Pan-African in Cameroon, in general and its northern domain, in particular, to tilt on detailed description of different tectonic events. Fold geometry has been used since the last century as (i) key for the better understanding of the tectonic and (ii) basis for kinematical analysis (Ramsay 1967; Hudleston 1973; Ramsay and Huber 1987; Zagorcev 1993; Bastida et al. 1999; Bobillo-Ares et al. 2004). Fold analysis seems to be one of multiple methods of basement rocks analysis.

To describe and classify the shape of folded surfaces, certain authors have recommended different types of function (Hudleston 1973; Ramsay and Huber 1987; Bastida et al. 1999; Aller et al. 2004) and others have classified natural fold shapes by comparing them to cubic Bézier curves (Srivastava and Lisle 2004; Coelho et al. 2005). One of the four classification schemes: (1) cubic Bézier curves (Bézier 1966, 1967) uniquely defined by the position of points marking the ends of the curve and control points; (2) conic sections (Aller et al. 2004) based on a drawback of using eccentricity as a classification parameter; (3) superellipses (Gardner 1965) that describes a generalized equation of an ellipse; and (4) power functions (Bastida et al. 1999) based on the comparison with the profile shapes geological folds can be used to better characterise folds in a given study area.

Structural geologists seek ways of untying ductile strain in orogenic belts, but there are few reliable ways of measuring ductile strain in rocks that do not contain classical 'strain markers', or are folded (Shah and Srivastava 2006). In this situation, flattened parallel folds, developed by superimposition of a homogeneous strain on parallel folds, can be used as a potential indicator for revealing the flattening component of strain history (Mukhopadhyay 1965; Hudleston 1973; Gray and Durney 1979; Ramsay and Huber 1987).

In this study, due to the fact that folds are common structures in many ductile zones, we perform fold-shape analysis associated with field observations with the aim to show their contribution to the structural characterization of the Numba ductile deformation zone (NDDZ) associated with the Pan-African tectonic in central Africa.

\section{Geological setting and previous work}

The Pan-African Belt of central Africa (PBCA; Bessoles and Trompette 1980) is also known as (1) Neoproterozoic Central African Fold Belt (CAFB;
Penaye et al. 1993; Toteu et al. 2001) that will be preferentially used in this study or (2) Pan-African North Equatorial fold belt (Nzenti et al. 1988). It is connected with the Neoproterozoic Brasiliano fold belt (Brito Neves et al. 2002; Cordani et al. 2003) as shown in figure 1(a) from Caby et al. (1991). However, it is less well known. In Cameroon, the Pan-African tectonic evolution is characterised by large scale shear zones, such as the Adamaoua shear zone (ASZ), Buffle Noir Mayo Baléo (BNMB) shear zone also known as Tcholliré-Banyo fault (TBF), Sanaga shear zone (SSZ), Mayo Nolti shear zone (MNSZ), Rocher du Loup shear zone (RLSZ) and Godé-Gomaya shear zone (GGSZ) that have transposed earlier structures (figure 1b).

The CAFB is divided into three domains (figure 1b, Toteu et al. 2004):

(1) the northern domain (or Poli domain or west Cameroon domain) limited to the south by the BNMB shear zone;

(2) the central domain located between the BNMB shear zone to the north and the Sanaga shear zone (SSZ) to the south;

(3) the southern domain (also known as Yaoundé domain) located between the SSZ to the north and the northern border of the Congo Craton to the south.

The northern domain comprises the sinistral N-S Godé-Gormaya and Mayo Nolti shear zones and the NE-SW Tcholliré-Banyo shear zone (figure 1b). This domain, which contains the study area, consists of Neoproterozoic volcanosedimentary schists, gneisses (with possible 2.1 Ga (U/Pb zircon; Penaye et al. 1993; Toteu et al. 1994, 2001) inheritance) and orthogneiss (Toteu 1990). The volcanic rocks display both tholeitic and alkaline affinities. The northern domain comprises: the Poli region, the Mayo Baléo region in the south and the Tcholliré region in its eastern part. In the Poli region, $\mathrm{E}-\mathrm{W}$ antiform and synform characterise gentle folding of a regional flat-lying foliation and lineation probably formed during an early thrust evolution. Sheath-like folds coeval with the early foliation materialise intense shear deformation during thrusting (Ngako and Njonfang 2011). The geometry of the folds varies eastwards, from open to tight profiles correlatively with a progressive change of the axial plane cleavage from crenulation to mylonitic at the contact zone with the BNMB shear zone (figure 1b). According to Ngako (1999), the Vallée des Roniers and the Demsa shear zones (both in the Poli domain) are coeval with down-slip movements parallel to the Godé Gormaya segments (figure $1 \mathrm{~b}$ ) both $\mathrm{E}-\mathrm{W}$ and $\mathrm{N}-\mathrm{S}$ mylonites determine a complex transtensive system. These shear zones seem to be coeval with the Z-shaped rotation 


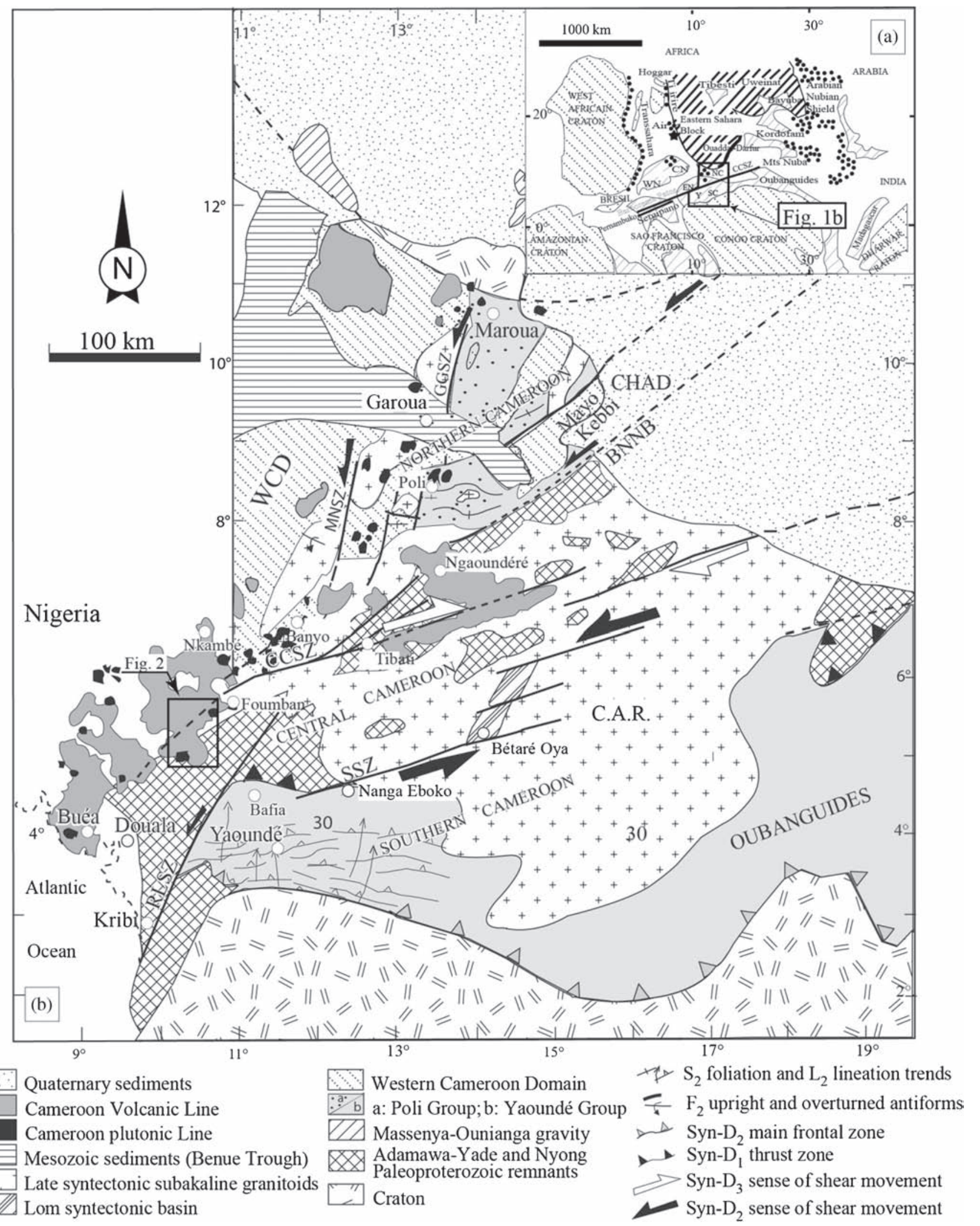

Figure 1. (a) Geological sketch map of central-north Africa (western Gondwana) (Ngako et al. 2008; redrawn and reinterpreted from Küster and Liégios 2001). (b) Pan-African structural map of Cameroon (Ngako et al. 2008; modified and re-interpreted from Toteu et al. 2001). Large grey arrow represents syn- $\mathrm{D}_{1-3}$ regional main stress direction. Thick lines = shear zone $(\mathrm{SZ}) ; \mathrm{BSZ}=$ Balché SZ; BNMB = Buffle Noir-Mayo Baléo; CCSZ = Central Cameroon SZ; GGSZ = Godé-Gormaya SZ; MNSZ = Mayo Nolti SZ; RLSZ = Rocher du Loup SZ; SSZ = Sanaga SZ. 
of the region, associated with $\mathrm{N}-\mathrm{S}$ crenulation cleavage $\mathrm{S}_{2} / \mathrm{S}_{3}$. Further to the south, in the Mayo Baléo region, these folds are overturned westwards, indicating large scale thrust movements coeval with E-W stretching lineations (Ngako et al. 2008). $\mathrm{Pb}-\mathrm{Pb}$ evaporation ages of ca $600 \pm 27 \mathrm{Ma}$ on monozircons from syn-thrust intrusions in Mayo Baléo give an age approximation of this second folding phase (Ngako 1999). The Tcholliré region consists of poly-deformed biotite-amphibole gneiss and orthogneiss with minor occurrences of metapelites and garnet amphibolites. These formations are also observed in the Banyo region in the southern extension of the Poli region (Ngako 1999; Toteu et al. 2004). The tectonic evolution of the Tcholliré area comprises an early $\mathrm{D}_{1}$ deformation with probably a flat-laying $\mathrm{S}_{1}$ foliation followed by $\mathrm{D}_{2}$ folding characterised by sub-vertical axial planar $\mathrm{S}_{2}$ foliation. The last stage of deformation inducing the $\mathrm{D}_{3}$ shear zones (e.g., Tcholliré-Banyo shear zone) controls the emplacement of late tectonic granitoids. The domain is then characterised by three deformation events with an earlier $\mathrm{D}_{1}$ event of gentle folding of a regional flat-lying foliation, a $\mathrm{D}_{2}$ folding event and $\mathrm{D}_{3}$ event inducing shear zones.

The Numba ductile deformation zone is a dextral shear zone oriented NE-SW on the western and the northeastern borders of the Numba granitic pluton. It extends from Bokwa to the south to Bambi to the north. This shear zone is sub-parallel to the documented Fotouni-Fondjomekwet mylonitic zone (FFMZ; Njanko et al. 2010; Tcheumenak Kouémo et al. 2014) situated $75 \mathrm{~km}$ southeastern part of the Numba granitic pluton and constitutes the basement rock of the granitic pluton.

\section{Materials and methods}

In this study, we use classical field methods, Cubic Bézier curves method, conic sections method and Ramsay's fold classification method.

A total of 11 observation stations from Widikum, Bambi and Bokwa localities were distributed among the study area. Fold profiles of six representative pictures were chosen from six different stations. Measurements were collected in LGE (Laboratoire de Géologie de l'Environnement; University of Dschang, Cameroon) using Fold-Profiler program.

In classical field method, structural elements as folds (axial planes and axes), foliations and stretching lineations are recognizable at a metric or centimetric scale and their orientations (strike and dip) were measured. These data were statistically analyzed in the laboratory using Stereonet. Fold axes have been plotted in lower hemisphere Schmidt diagrams using conventional technique (figure 2).

Two quantitative methods are commonly used to describe fold-shape classification by visual comparison: the Ramsay method based on the use of three concepts (orthogonal thickness, t' $\alpha$; thickness parallel to the axial plane, $t_{0}$; and dip isogons, $\alpha$ ) and the mathematical function that fits folded surface. Although, the type of mathematical function used is different, there are many features: (i) classification of the shapes of individual limbs, rather than the shapes of the entire folds; (ii) the mathematical functions that form the basis of the fold description; (iii) two-fold shape classification parameters; and (iv) the way of converting the shape parameter. Lisle et al. (2006) have developed the Fold Profiler: A Matlab-based program for fold-shape classification that contains several methods, based on different mathematical functions which accurately fit natural fold profiles. This program incorporates four methods: cubic Bézier curves, conic sections, power functions and superellipses. Liu et al. (2009) have developed the BézierFold Profiler method. We favour the cubic Bézier curves method compared with the conic sections method, due to the nature of the folds to be fitted and the aim of our study. The file containing the digital image of representative fold to be analyzed was imported into the Matlab Fold Profiler software and displayed on the screen. Following the onscreen instructions, each fold limb is analyzed separately as described by Srivastava and Lisle (2004) and Lisle et al. (2006). Ramsay's folded surfaces classification is based on thickness variations. On a profile plane view of a fold, we first mark the hinge points and inflection points on the two bounding surfaces of the folded layer, and then draw the tangents to the folded layer at the hinge points.

\section{Field observations and characteristics of folds}

The study area is made up of granitic pluton that intrudes a basement rock mostly made of banded amphibole gneiss (figure 2). It crops out in the form of flagstone in Widikum, Bambi and Bokwa. Grey in colour, the banded amphibole gneiss are medium- to fine-grained (average size $<1.5 \mathrm{~mm}$ ) with a preferred orientation of their minerals and a granoblastic texture. They are composed of biotite, hornblende, plagioclase, K-felsdpar and quartz. Accessory minerals are sphene, zircon, apatite and oxides.

Gneissic foliation dips moderately to highly towards the NW and SE (figure 2) implying, at the regional scale, folded surfaces. Folding events 


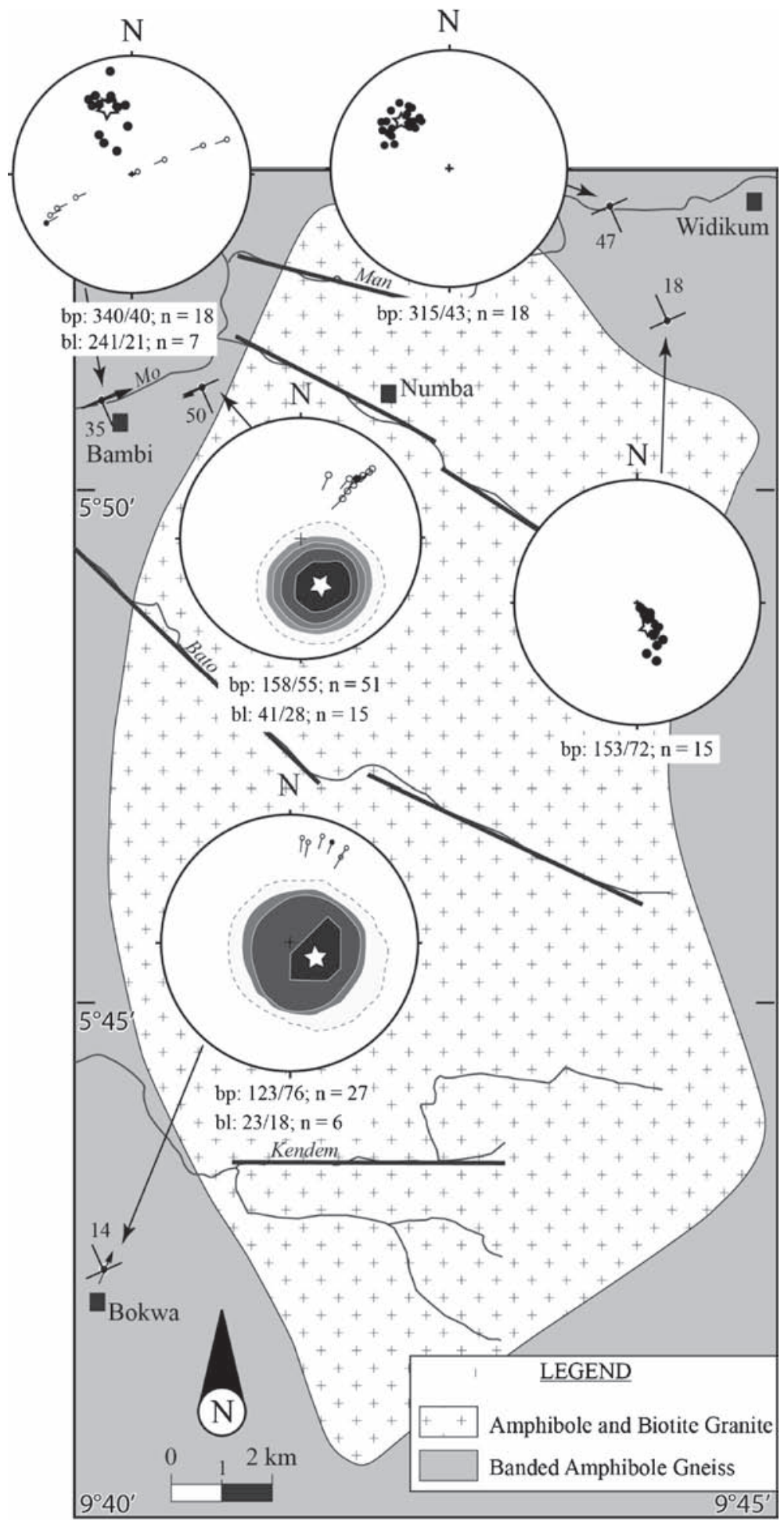

Figure 2. Geological map of the Numba area and projection diagrams for $\mathrm{S}_{2}$ foliation poles and $\mathrm{F}_{2}$ fold axes. bp $=$ best pole; bl = best line.

observed in this area are linked to three deformation phases. Folds are clearly visible on the field where they occur generally as centimetre or metre size and show different morphological aspects: (i) recumbent folds; (ii) anisopaque folds, and (iii) disharmonic folds in Bokwa, Bambi and Widikum (figure 3). Most folds of the NDDZ are of Z-shape.
Their short limbs appear to have rotated clockwise with respect to their long limbs. Their wavelength varies from 0.42 to $1.5 \mathrm{~m}$ and the amplitude between 0.17 and $1 \mathrm{~m}$. Most of them are closed folds with hinges thicker than the limbs. Regularly, short limbs are sheared, thin and defined a shear plane of dextral movement (figure 3). 
$\mathrm{F}_{1}$ folds are the result of the folding of an earlier $\mathrm{S}_{1} \mathrm{E}-\mathrm{W}$ gneissic foliation that is progressively transposed into $\mathrm{S}_{2}$. They show asymmetric morphology and occur as centimetric to decimetric intrafolial folds. Their axes plunge $<15^{\circ}$ towards the NNE or SSW. The quartzo-feldspathic bands of the folds are thicker than ferromagnesian one and also, long limbs relatively to the short limbs.

$\mathrm{F}_{2}$ folds are multi-layered with mostly asymmetric Z-shapes (figure 3c). Their sizes vary from centimetre to decametre scale. They show (i) an axial planar schistosity (mostly parallel to the $\mathrm{L}_{2}$ stretching lineation) $\mathrm{S}_{2}$ marked by stretched quartz crystals, biotite flakes and amphibole crystals and (ii) consistent asymmetry and $\mathrm{SE}$ vergence. $\mathrm{F}_{2}$ fold axes in the Numba area have similar orientations with axes plunging $12^{\circ}-28^{\circ}$ towards the NE or SW. Best lines are at 241/21 and 41/28 in Bambi and 23/18 in Bokwa.
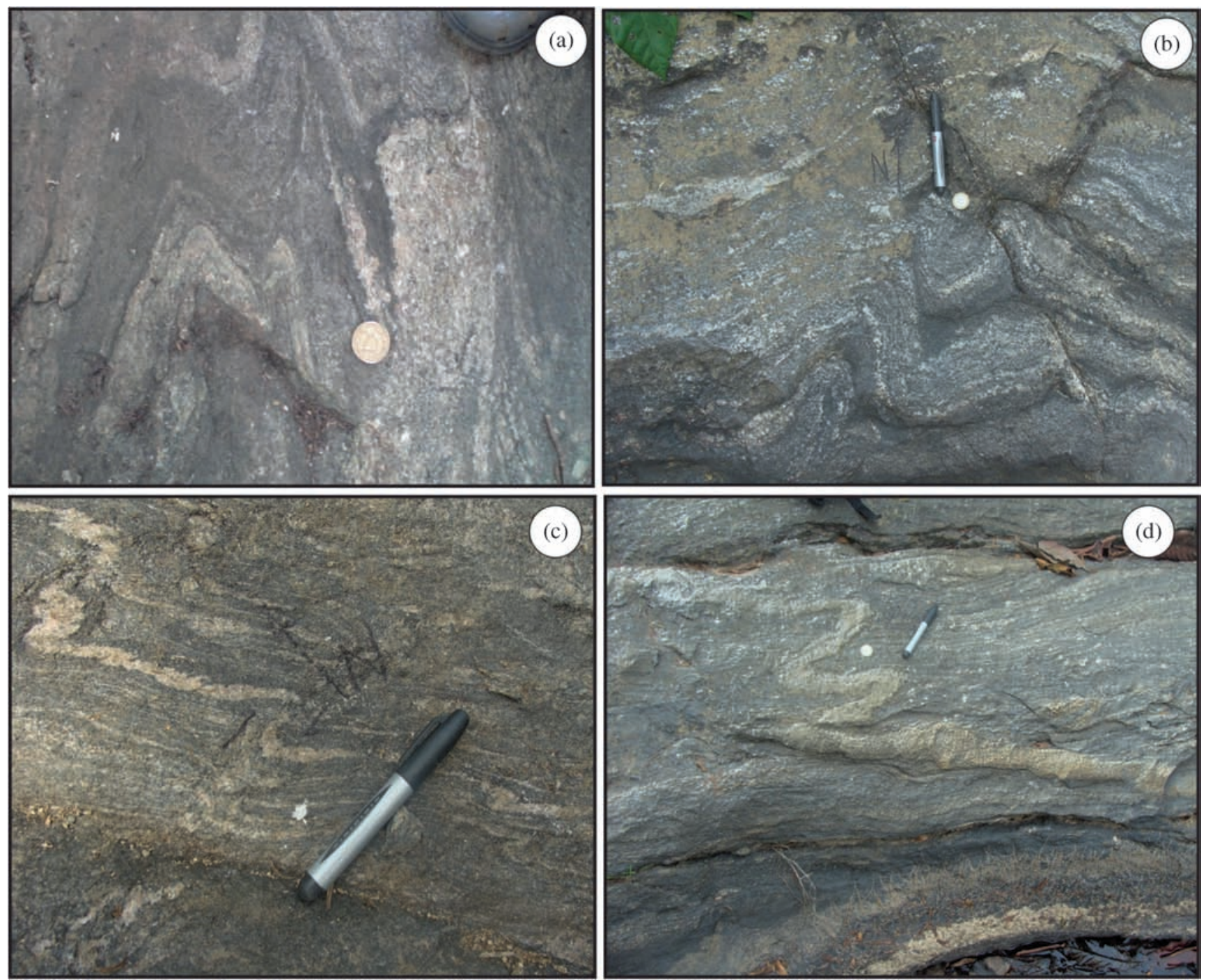

$\mathrm{F}_{3}$ folds are materialised by the folding of a fine grain granite vein in the Bokwa area (figure $3 \mathrm{~d}$ ). The size of the folds is in decimetre scale. The axial planar schistosity of $\mathrm{F}_{3}$ folds (well developed in the hinges) is marked by stretched quartz crystals and biotite flakes. Most of $\mathrm{F}_{3}$ fold axes plunge $56^{\circ}-72^{\circ}$ towards the NE.

\section{Results}

\subsection{Fold-shape analysis}

In the study, three main parameters are obtained: aspect ratio (R), normalized area (a) and eccentricity (e). $F_{1}$ folds are mainly plotted in the parabolic shape fold domain (78\% of the measurements) event if there are some measurements in the sine shape fold domain (figure 4a). Considering the

Figure 3. Representative fold shapes determined by Fold Profiler ${ }^{\circledR}$. (a) $F_{1}$ folds from Bokwa; (b and $\mathbf{c}$ ) $F_{2}$ folds from (b) Bambi and (c) Widikum, respectively and (d) $\mathrm{F}_{3}$ folds from Bokwa. 
normalized area and the eccentricity parameters, $83 \%$ of the measurements are grouped around the parabolic shape fold.

$\mathrm{F}_{2}$ folds are plotted in the parabolic and sine shape fold domains. In fact, their normalized area values vary between 1.1 and 1.4 for $87 \%$ of the measurements (figure $4 \mathrm{~b}$ ). The aspect ratio values of $\mathrm{F}_{2}$ folds vary between 0.4 and 3.1 , while the variation of the eccentricity parameter $(0.8-1.5)$ allow to plot $54 \%$ of the measurements in the parabolic shape fold domain and $41 \%$ in the hyperbolic fold shape domain.

$\mathrm{F}_{3}$ folds are scattered between sine and parabolic shape fold domains where they represent respectively $40 \%$ and $30 \%$ of the measurements (figure 4c). The eccentricity parameter values are comprised between 0.9 and 1.2, with $90 \%$ of the measurements plotted in the parabolic fold shape domain.

Folds from the study area are scattered in the sine shape fold (with $12 \%, 39 \%$ and $40 \%$ of the measurements corresponding respectively to $\mathrm{F}_{1}, \mathrm{~F}_{2}$ and $\mathrm{F}_{3}$ folds), parabolic shape fold (with $78 \%$, $48 \%$ and $30 \%$ of the measurements corresponding respectively to $F_{1}, F_{2}$ and $F_{3}$ folds) and elliptical shape fold domains. Parabolic shape folds are mainly represented with $52 \%$ of the measurements, followed by sine shape folds $(30 \%$ of the
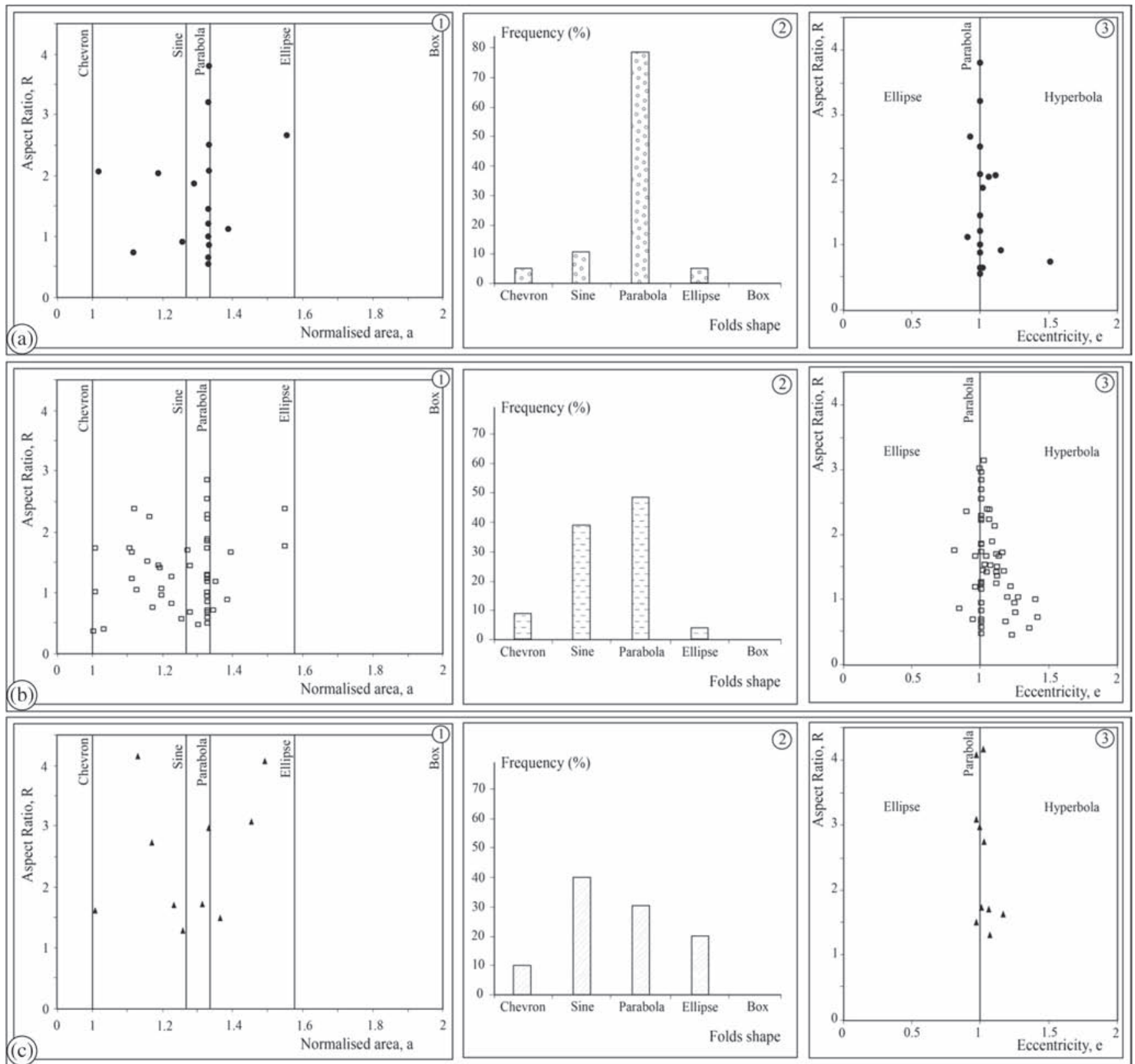

Figure 4. Fold-shape analyses aspect ratio vs. normalized area (1) with corresponding histogram, (2) aspect ratio vs. eccentricity and (3) determined by conic sections method for (a) $\mathrm{F}_{1}$ folds, (b) $\mathrm{F}_{2}$ folds and (c) $\mathrm{F}_{3}$ folds. 
measurements) and elliptical shape folds are $18 \%$. According to Aller et al. (2004), the best approximation of fold shape should take in consideration the eccentricity (e) of the conic section. Based on the aspect ratio vs. eccentricity diagram, the almost whole measurements seem to be regrouped around the parabolic shape folds event if some measurements plot in the hyperbolic shape fold domain, where they show a great value of eccentricity for low values of aspect ratio.

\subsection{Geometric analysis of folded layers}

The method using the t' $\alpha$ vs. $\alpha$ diagram (figure 5) of Ramsay and Huber (1987) is based on layer thickness variations. Folds from the study area are located in class $1 \mathrm{C}$ and class $3 . \mathrm{F}_{1}$ and $\mathrm{F}_{3}$ folds are ranged in class $1 \mathrm{C}$ field, while $\mathrm{F}_{2}$ folds cover a large field ranging from class $1 \mathrm{C}$, class 2 to class 3 fields. The Numba folds, developed in banded amphibole gneiss mostly characterised by alternation of competent quartzo-feldspathic bands with biotite-amphibole rich incompetent bands, indicate different folding behaviours for the two bands. Competent bands plot mostly in class $1 \mathrm{C}$ and class 3 while incompetent bands plot in class $1 \mathrm{C}$ and class 2 (?). $\mathrm{F}_{1}$ and $\mathrm{F}_{2}$ are materialized by the folding of gneissic bands, while $\mathrm{F}_{3}$ folds are the result of folding of a fine-grained granitic vein intruding the banded amphibole gneiss (figure 3 ).

\section{Interpretation and discussion}

The Numba ductile deformation zone is characterised by banded amphibole gneiss in which fine-grained granitic veins are folded. The morphology of folds in the NDDZ (figure 3a-d) points to (i) asymmetric fold shapes with dominant Z-folds and (ii) a dextral sense of shear motion. It is well demonstrated that fold geometry and folding mechanism depend on physical properties and physico-chemical conditions of the folded bands. The morphology of the NDDZ folds is similar to the morphology of those described and categorized by Carreras et al. (2005), in the dextral Cap De Creus shear zone. They show the typical geometry of synthetic folds characterised by a thinned short limb that occur in dextral ductile shear zone. Folds Profiler characterised folds from the NDDZ in the conic section plots (figure 4) as parabolic shape for $\mathrm{F}_{1}$ folds, parabolic shape to hyperbolic shape for $\mathrm{F}_{2}$ and $\mathrm{F}_{3}$ folds based on the normalized fold area and/or eccentricity parameters. The co-existence of parabolic shape, hyperbolic shape and sine shape folds can be attributed to the increasing of the normalized fold area and fold amplitude both linked to the importance of the flattening component in the deformation.

Folds from NDDZ mostly belong to class 1C, class 2 and class 3 fields of the t' $\alpha$ vs. $\alpha$ diagram of Ramsay and Huber (1987) (figure 5). The slope of the curves obtained on the t' $\alpha$ vs. $\alpha$ diagram indicates that $\mathrm{F}_{1}$ and $\mathrm{F}_{3}$ folds belong to class $1 \mathrm{C}$ field, while $\mathrm{F}_{2}$ folds have various shapes ranging from class 1C, class 2 and class 3 fields. According to Ramsay (1967), Lisle (1997) and Srivastava and Shah $(2006,2008)$, the formation of Ramsay class $1 \mathrm{C}$ folds is due to the flattening (superposition of homogeneous ductile strain) on a parallel fold. At high angle to the shear direction, folds display a rather open shape with axial plane forming moderate angle to the shear zone and they plot predominantly as type 1C of Ramsay's classification (Carreras et al. 2005). The class 3 fold shape involves the susceptibility of the less competent
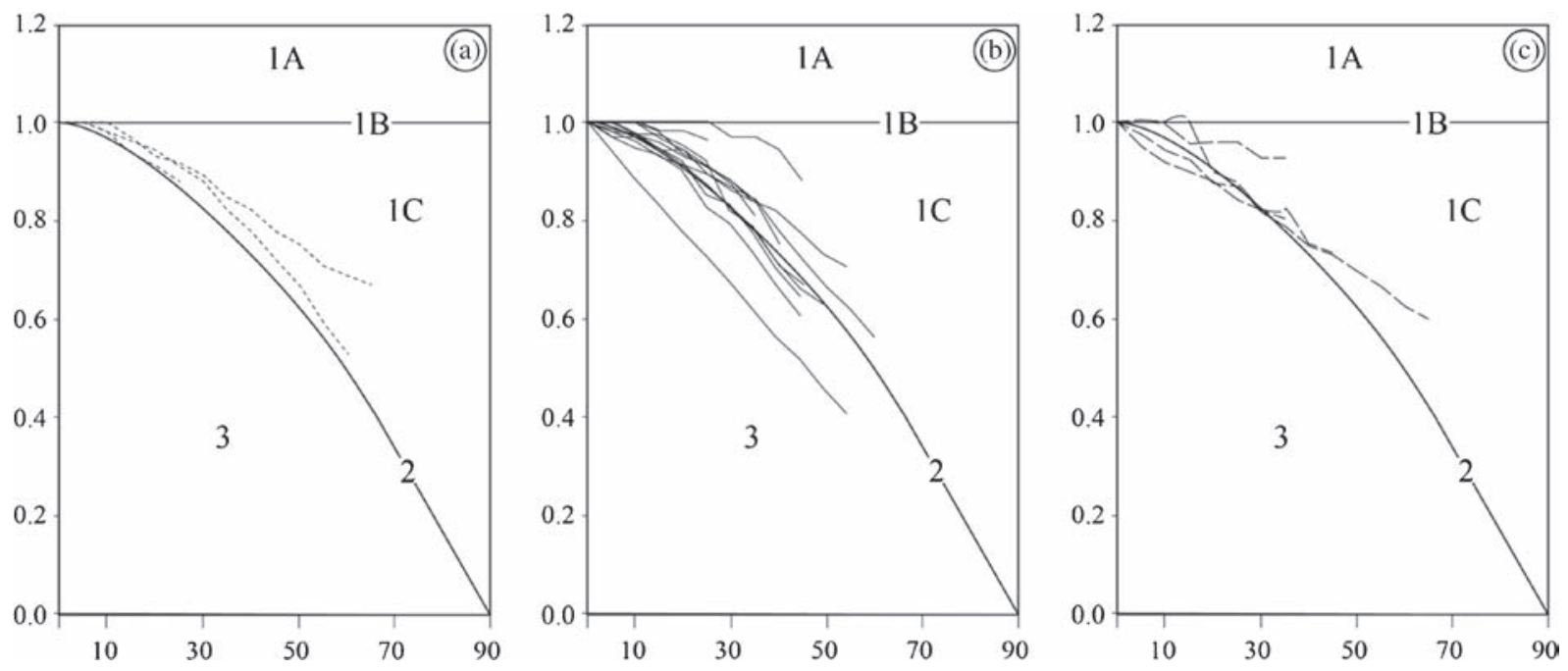

Figure 5. t' $\alpha$ vs. $\alpha$ diagram of Ramsey classification for (a) $F_{1}$, (b) $F_{2}$ and (c) $F_{3}$ folds. 
nature bands (quartz and feldspar rich) opposite to the ferromagnesian more competent nature bands to ductile deformation. Fold shape in competent bands varies with ductility contrast between the competence of adjacent bands (Ramsay 1967).

The results obtained in this study clearly classified the folding of the basement rock in the study area and indicate that these data should be taken into account when characterizing the tectonic evolution of the western domain of the CAFB in Cameroon, in particular and of the whole central Pan-African belt, in general.

\section{Conclusion}

The NDDZ is characterised by banded amphibole gneiss that recorded three deformation phases recognizable by $F_{1}, F_{2}$ and $F_{3}$ folds. The morphology of folds points to asymmetric fold shapes with dominant Z-shapes. The geometric analysis of the folds in the study area points preferably to parabolic shape and hyperbolic shape folds for $F_{1}, F_{2}$ and $\mathrm{F}_{3}$ folds. In the Ramsay classification diagram, $\mathrm{F}_{1}$ and $F_{3}$ folds belong to class $1 \mathrm{C}$ field while $\mathrm{F}_{2}$ folds belong to class 1C, class 2 and class 3 fields. Field observations and the fold shapes allow us to conclude that the NDDZ underwent ductile dextral shear movement that takes into account the banding of the banded amphibole gneiss and folding mechanisms that associate simple shear with an important compressive component. These results demand the need to take into consideration the folding events for the understanding of the tectonic evolution of the western domain of the CAFB.

\section{References}

Aller J, Bastida F, Toimil N C and Bobillo-Ares N C 2004 The use of conic sections for the geometrical analysis of folded surface profiles; Tectonophys. 379(1-4) 239-254.

Aller J, Bobillo-Ares N C, Bastida F, Lisle R J and Menéndez C O 2010 Kinematic analysis of asymmetric folds in competent layers using mathematical modeling; J. Struct. Geol. 32 1170-1184.

Bastida F, Aller J and Bobillo-Ares N C 1999 Geometrical analysis of folded surfaces using simple functions; J. Struct. Geol. 21(7) 729-742.

Bessoles B and Trompette R 1980 La chaîne panafricaine: Zone mobile d'Afrique centrale (partie sud) et zone mobile soudanaise. Mémoire BRGM no. 92.

Bézier P 1966 Définition numérique de courbes et surfaces, part 1; Automatisme 11 625-632.

Bézier P 1967 Définition numérique de courbes et surfaces, part 2; Automatisme 12 17-21.

Bobillo-Ares N C, Toimil N C, Aller J and Bastida F 2004 'Fold Modeler': A tool for the geometrical and kinematical analysis of folds; Comput. Geosci. 30(2) 147-159.

Brito Neves B B, Van Schmus W R and Fetter A 2002 Northwestern Africa-Northeastern Brazil: Major tectonic links and correlation problems; J. African Earth Sci. 34 275-278.

Caby R, Sial A N, Arthaud M and Vauchez A 1991 Crustal evolution and the Brasiliano orogeny in northeast Brazil; In: The West African Orogens and Circum-Atlantic Correlatives (eds) Dallmeyer R D and Lécorché J C P L, Springer-Verlag, Berlin, pp. 373-397.

Carreras J, Druguet E and Griera A 2005 Shear zone-related folds; J. Struct. Geol. 27 1229-1251.

Coelho S, Passchier C and Grasemann B 2005 Geometry description of flanking structures; J. Struct. Geol. 27(4) 597-606.

Cordani U G, D'Agrella-Filho M S, Brito Neves B B and Trindade R I F 2003 Tearing up Rodinia: The Neoproterozoic palaeogeography of south American cratonic fragments; Terra Nova 15 350-359.

Ganno S, Nzenti J P, Kankeu B and Ngnotue T 2010 Geometric analysis of superposed folds in the Kimbi area (Cameroon Pan-African fold belt) based on the Fold Profiler method; Comput. Geosci. 36 1053-1059.

Gardner M 1965 The superellipse: A curve that lies between the ellipse and the rectangle; Scientific American AA21 222-234.

Gray D R and Durney D M 1979 Investigation on the mechanical significance of crenulation cleavage; Tectonophys. 58 35-79.

Hudleston P J 1973 Fold morphology and some geometrical implications of theories of fold development; Tectonophys. 16(1-2) 1-46.

Küster D and Liégios J P 2001 Sr, Nd isotopes and geochemistry of the Bayuda desert high-grade metamorphic basement (Sudan): An early Pan-African oceanic convergent margin, not the edge of the East Saharan Ghost Craton? Precamb. Res. 109 1-23.

Lisle R J 1997 A fold classification scheme based on a polar plot of inverse layer thickness; In: Evolution of geological structures in micro to macro-scales (ed.) Sengupta S, Chapman \& Hall, London, UK, pp. 323-339.

Lisle R J, Fernandez Martinez J L, Bobillo-Ares N, Menéndez O, Aller J and Bastida F 2006 Fold profiler: A Matlab-based program for fold shape classifications; Comput. Geosci. 32(1) 102-108.

Liu C, Zhang Y and Wang Y 2009 Analysis of complete fold shape based on quadratic Bézier curves; J. Struct. Geol. 31(6) 575-581.

Mukhopadhyay D 1965 Effects of compression on concentric folds and mechanism of similar folding; J. Geol. Soc. India 6(1) $27-41$.

Ngako V 1999 Les Déformations continentales panafricaines en Afrique Centrale. Résultat d'un poinçonnement de type himalayen; Doctorat d'Etat thesis, University of Yaoundé I, Cameroon, $301 \mathrm{p}$.

Ngako V, Affaton P and Njonfang E 2008 Pan-African tectonic in northwestern Cameroon: Implication for history of western Gondwana; Gondwana Res. 14 509-522.

Ngako V and Njonfang E 2011 Plates amalgamation and plate destruction, the Western Gondwana history; In: Tectonics (ed.) Closson Damien, INTECH, UK, pp. 3-36. Njanko T, Nédélec A, Kwékam M, Siquiéra R and Estéban L 2010 Emplacement and deformation of the Fomopéa pluton. Implication for the Pan-African history of western Cameroon; J. Struct. Geol. 30 1-15.

Nzenti J P, Barbey P, Macaudiere J P and Soba D 1988 Origin and evolution of the late Precambrian high grade Yaoundé gneisses (Cameroon); Precamb. Res. 38 91-109.

Penaye J, Toteu S F, Van Schmus W R and Nzenti J P 1993 Données géochronologiques préliminaires (U-Pb et Sm-Nd) sur la série de Yaoundé: âge du métamorphisme granulitique de la zone mobile; Comptes Rendus de l'Académie des Sciences (Paris) 317 789-797. 
Ramsay J G 1967 Folding and Fracturing of Rocks; McGrawHill Book Company, New York, 568p.

Ramsay J G and Huber M I 1987 Modern Structural Geology. Folds and Fractures; vol. 2, Academic Press, London, 700p.

Shah J and Srivastava D C 2006 Strain estimation from flattened parallel folds: Application of the Wellman method and Mohr circle; Geol. Mag. 143 243-247.

Srivastava D C and Lisle R J 2004 Rapid analysis of fold shape using Bézier curves; J. Struct. Geol. 26(9) 15531559 .

Srivastava D C and Shah J 2006 A rapid method for strain estimation from flattened parallel folds; J. Struct. Geol. 28(1) 1-8.

Srivastava D C and Shah J 2008 The 'isogon rosette' method for strain estimation of strain in flattened folds; J. Struct. Geol. 30(4) 444-450.

Tcheumenak Kouémo J, Njanko T, Kwékam M, Naba S, Bella Nké B E, Yakeu Sandjo A F, Fozing E M and Njonfang E 2014 Kinematic evolution of the FodjomekwetFotouni shear zone (west Cameroon): Implications for emplacement of the Fomopéa and Bandja plutons; J. African Earth Sci. 99 261-275.

Toteu S F 1990 Geochemical characterisation of the main petrographical and structural units of Northern Cameroon; implications for the Pan-African evolution; J. African Earth Sci. 10 615-624.

Toteu S F, Penaye J and Poudjom Djomani Y 2004 Geodynamic evolution of the Pan-African belt in central Africa with special reference to Cameroon; Canadian J. Earth Sci. 41 73-85.

Toteu S F, Van Schmus R W, Penaye J and Michard A 2001 New U-Pb and Sm-Nd data from north-central Cameroon and its bearing on the Pre-Pan-African history of central Africa; Precamb. Res. 108 45-73.

Toteu S F, Van Schmus W R, Penaye J and Nyobé J B $1994 \mathrm{U}-\mathrm{Pb}$ and Sm-Nd evidence for Eburnean and PanAfrican high-grade metamorphism in cratonic rocks of southern Cameroon; Precamb. Res. 67 321-347.

Zagorcev I 1993 The geometrical classification of folds and distribution of fold types in natural rocks; J. Struct. Geol. 15(3-5) 243-251.

MS received 20 February 2015; revised 21 December 2015; accepted 19 October 2016

Corresponding editor: SAIBAL Gupta 